\title{
Chemical compositions and antioxidant activities depending on cultivation methods and various parts of yuza
}

\author{
Jong Eun Lee ${ }^{1}$, Kyung Mi Kim ${ }^{1 *}$, Jin Sook Kim ${ }^{2}$, Gi Chang Kim ${ }^{1}$, Song Yi Choi ${ }^{1}$, \\ Sang Bum Kim ${ }^{1}$ \\ ${ }^{l}$ Deptment of Agrofood Resources, National Institute of Agricultural Science, Rural Development Administraction, \\ Wanju 55365, Korea \\ ${ }^{2}$ Agriculture Export Division, Rural Development Administraction, Jeonju 54875, Korea
}

\section{유자 재배방법에 따른 부위별 화학적 성분 및 항산화 활성}

\author{
이종은 ${ }^{1} \cdot$ 김경미 $^{1 *} \cdot$ 김진숙 $^{2} \cdot$ 김기창 $^{1} \cdot$ 최송이 $^{1} \cdot$ 김상범 $^{1}$ \\ 1농촌진흥청 국립농업과학원 농식품자원부, \\ 2농촌진흥청 수출농업지원과
}

\begin{abstract}
This study was conducted to investigate the quality properties depending on the cultivation methods (general, organic, pesticide-free) of yuza and its various parts (peel, pulp, seed). The contents of hesperidin were the highest in yuza feel grown by pesticide-free method $(13.23 \mathrm{mg} / \mathrm{g})$. The contents of naringin presented a higher content in the peel, especially which of the general $(4.62 \mathrm{mg} / \mathrm{g})$ showed the highest value. Vitamin $\mathrm{C}$ analysis showed the highest content in the peel, significantly varied according to the cultivation method and various parts $(p<0.05)$. Vitamin $\mathrm{C}$ value was significantly highest in organic peel, which was $770.02 \mathrm{mg} / 100 \mathrm{~g}$, whereas among the peel, the pulp and the seed were it the lowest in the seed. The content of total polyphenols were the highest in general peel $(0.85 \mathrm{mg} / \mathrm{g})$. Flavonoid content of pesticide-free seed was significantly higher than those of the other yuja samples which was $0.89 \mathrm{mg} / \mathrm{g}(\mathbf{p}<0.05)$. The DPPH radical scavenging activity was relatively more active in the peel among the above-mentioned three parts, especially the pesticide-free peel was most active, which was $73.94 \%$. The ABTS radical scavenging activity of organic peel was significantly active among the samples, which was $84.47 \%(p<0.05)$. Based on these results, it can be said that yuja has variety of useful components in the pulp and the seed as well as the peel: and thus it's hight recommended to develop more varied yuja products.
\end{abstract}

Key words : yuja, chemical compositions, antioxidant activities

\section{서 론}

식물 분류학상 유자(Citrus Junos Sieb.)는 운향과 감귤속 에 속하며, 한국, 중국 및 일본 등지에서 재배되고 있는데, 한국산 유자의 향이 우수한 것으로 알려져 있다 $(1,2)$. 유자

*Corresponding author. E-mail : kimkm@korea.kr Phone : 82-63-238-3556, Fax : 82-63-238-3842

Received 6 September 2017; Revised 25 September 2017; Accepted 26 September 2017.

Copyright (c) The Korean Society of Food Preservation. All rights reserved.
나무는 일반 감귤에 비해 내한성 및 내건성에 강하여 겨울 철 온난한 기후에서 재배가 가능하므로 국내의 제주도, 고 흥, 거창, 장흥, 완도, 거제 등 주로 남해안 일대에서 재배되 어 왔다(3). 국내에서 유자의 생산량과 재배면적은 해마다 증가하고 있으나 낮은 저장성과 짧은 수확기간으로 생과실 로서의 이용이 어려워 생산량에 비하여 낮은 소비량을 나타 내고 있다 $(2,4)$.

유자는 다른 감귤류와는 다르게 과육 뿐 만 아니라 과피 까지 이용할 수 있는 과실로 유자 특유의 향과 무기질, 구연 산 등이 함량이 높아 주로 차, 음료 및 향료로 이용되고 있는데, 특히 성숙과는 과육에 비해 과피의 비율이 높다고 
알려져 있다(2).

유자에는 비타민 A, B, C, 유기산 및 무기질이 많이 함유 되어 있으며, 특히 유자의 비타민 C는 레몬보다 3 배 많은 양으로 피부미용 및 감기에 효과적이다(5). 또한 유자에 함유되어 있는 헤스페리딘 및 리모닌 등의 플라보노이드 성분은 항염증, 항산화, 혈압강하, 항알러지 및 라디컬 소거 능에 효과적이라고 알려져 있다(6).

최근 소비자들의 기능성 식품 및 건강식품에 대한 관심 과 요구가 높아지고 있고 소비 패턴의 다양화에 따라 우리 농산물의 소비 활성화와 수요 확대를 위해서는 소비자의 기호를 충족시킬 수 있는 제품 개발이 이루어져야 한다고 생각된다. 그러나 유자의 가공형태는 아직까지도 설탕에 절인 형태인 유자차로 대부분 소비되고 있어 계절적 제약을 벗어나 누구나 손쉽게 간편하게 접할 수 있는 새로운 유자 수요 창출이 절실하다.

한편, 주로 과피만을 이용하는 유자차 제조과정 중에 발 생하는 유자즙은 상당부분 이용되지 못하고 폐기되는 실정 이다. 뿐만 아니라 이 때 부산물로 같이 발생하는 유자씨도 버려지고 있어 환경적인 측면에서도 유자 전체를 다양하게 활용할 수 있는 방안연구에 대한 필요성이 대두되고 있다 $(2,7)$.

지금까지 유자와 관련하여 선행되어온 연구로는 유자의 부산물에 관한 연구(6,7), 유자의 이화학적 성분분석 $(8,9)$, 유자의 가공 방법에 관한 연구(10-12) 및 유자 생리활성 관련 연구 $(3,13,14)$ 등이 있다. 또한 산지별 유자의 이화학 적 특성(15), 생리적 특성(2)을 비교하기도 하였으나 유자의 종류별, 부위별로 이화학성분과 생리활성을 동시에 식품학 적 측면에서 다양하게 검토한 자료는 미흡한 실정이다. 유 자의 부가가치 향상을 위한 가공제품과 관련된 연구로는 유자 분말이나 착즙액 형태로 첨가한 스펀지케익(16), 초코 릿(17), 식초(18), 설기떡(19), 아이스크림(20) 등이 있으나 건강을 위한 식품소재화로 유자 활용 가치를 높일 수 있는 측면에서는 미비하다.

따라서 본 연구는 유자의 이용률 및 유자 가공 시 폐기되 는 유자 부산물의 활용도를 높이기 위한 일환으로 국내 대표 유자산지인 전남 고흥에서 재배된 유자 종류별(일반, 유기농, 무농약 재배) 및 부위별(과피, 과육, 씨)에 따른 이화 학적 품질특성과 생리활성을 분석하여 향후 유자를 활용한 새로운 식품소재를 위한 기초자료로 이용하고자 한다.

\section{재료 및 방법}

\section{실험재료}

본 실험에 사용한 유자는 전남 고흥군 풍양면 지역 유자 제배 농가 중에서 고흥군농업기술센터로 부터 추천을 받았 으며 최대한 서로 인접한 곳에서 재배된 것으로 10 월-11월
에 수확된 유자를 일반, 무기농 및 유기농으로 각각 구분하 였다.

유자의 정지 전정, 적정 착과, 결실 관리, 물 관리 등은 일반, 무농약, 유기농 유자 모두 동일하게 하였고 비료와 병충해 방제는 무농약과 유기농 유자는 친환경 농산물 기준 에 맞게 사용하였다. 즉, 무농약 유자는 퇴비, 액비, 복합비 료를 각각 2 회씩 주는 반면에 유기농 유자는 화학비료 대체 를 위해 헤어리베치와 호밀을 혼파재배하여 질소 공급을 하고 표준 질소 시비량에 부족한 양은 친환경 유기질비료 (2.5-1.7-1.0)로 보충하였다. 특히, 무농약과 유기농 유자는 친환경 농산물 인증 농가에서 재배된 것으로 수확된 유자에 대한 잔류농약(245 성분) 검사서를 확인하였다. 또한 유자 시료는 15-20년생 고흥재래종이었으며 무작위로 15 개를 선별하여 과피, 과육 및 씨를 각각 나누어 동결건조기 (LP30, Ilshinbiobase, Daejeon, Korea)를 이용하여 급속 동결 한 후, 건조하였다. 건조된 시료는 분쇄 후 100 mesh 체에 내려 $-20^{\circ} \mathrm{C}$ 에서 보관하면서 시료로 사용하였다.

\section{일반성분}

유자 종류 및 부위에 따른 일반성분은 $\mathrm{AOAC}$ 방법(21)에 따라 측정하였다. 수분함량은 $105^{\circ} \mathrm{C}$ 상압 가열 건조법, 조단 백질 함량은 Kjeldahl법, 조지방은 soxhlet법, 조회분은 55 $0^{\circ} \mathrm{C}$ 직접 회화법으로 측정하였다.

유리당

유리당 분석은 Lee 등(2)의 방법을 변형하여 사용하였다. 시료 $1 \mathrm{~g}$ 을 증류수 $49 \mathrm{~mL}$ 에 넣고 추출 및 여과하여 50 $\mathrm{mL}$ 로 정용한 뒤 $4^{\circ} \mathrm{C}, 15,000 \mathrm{rpm}$ 에서 5 분간 원심분리 하였 다. 상등액을 $0.45 \mu \mathrm{m}$ membrane filter로 여과한 뒤 HPLC로 분석하였다. 이 때 HPLC 분석 조건으로 column은 Asahipak NH2P-504E(4.6×250 mm, Shodex, Tokyo, Japan), 용매는 $70 \%$ ACN(Fisher Co., Fair Lawn, NJ, USA), flow rate는 $1.0 \mathrm{~mL} / \mathrm{min}$ 이었고, 검출기는 $\mathrm{ELSD}$ (Agilent Technologies, Santa Clara, CA, USA)를 사용하였다. 유리당 함량은 fructose, glucose, sucrose, maltose(Sigma-Aldrich Co., St. Louis, MO, USA)을 표준물질로 이용하여 작성한 검량선 으로부터 계산하였다

유기산

유기산 분석은 Shin 등(3)의 방법을 변형하여 사용하였 다. 시료 $1 \mathrm{~g}$ 을 증류수 $49 \mathrm{~mL}$ 에 넣고 추출 및 여과하여 $50 \mathrm{~mL}$ 로 정용한 뒤 $4{ }^{\circ} \mathrm{C}, 15,000 \mathrm{rpm}$ 에서 5 분간 원심분리 하였다. 상등액을 $0.45 \mu \mathrm{m}$ membrane filter로 여과한 뒤 $\mathrm{HPLC}$ 로 분석하였다. HPLC 분석 조건으로 column은 Amine X HPx-87H Ion Exclusion column $(300 \times 7.8 \mathrm{~mm}$, Bio-RAD, Hercules, CA, USA), 용매는 $0.008 \mathrm{~N} \mathrm{H}_{2} \mathrm{SO}_{4}$, flow rate는 $0.6 \mathrm{~mL} / \mathrm{min}$ 이었고, 검출기는 $\mathrm{UV}$ detector(Waters, 
Milford, MA, USA)로 $210 \mathrm{~nm}$ 에서 측정하였다. 유기산 함량 은 oxalic acid, citric acid, malic acid, succinic acid, fumaric $\operatorname{acid}(\operatorname{Sigma-Aldrich}$ Co.)을 표준물질로 이용하여 작성한 검량선 으로부터 계산하였다

\section{Hesperidin 및 naringin}

유자 종류 및 부위에 따른 naringin 및 hesperidin 함량은 Davis변법(22)에 따라 수행하였다. 시료 $1 \mathrm{~g}$ 과 증류수 9 $\mathrm{mL}$ 를 가하여 추출한 뒤 $4^{\circ} \mathrm{C}, 12,000 \mathrm{rpm}$ 에서 15 분간 원심분 리 한 후 여과하여 $50 \mathrm{~mL}$ 로 정용한 추출물을 사용하였다. Naringin은 추출시료 $100 \mu \mathrm{L}$ 를 취한 후 $95 \%$ diethylene glycol 용액 $5 \mathrm{~mL}$ 및 $4 \mathrm{~N}-\mathrm{NaOH} 100 \mu \mathrm{L}$ 를 차례로 가하여 10 분 뒤 $420 \mathrm{~nm}$ 에서 흡광도를 측정하였다. Hesperidin의 경우 30 분 뒤 $360 \mathrm{~nm}$ 에서 흡광도를 측정하였다.

\section{Vitamin C}

Vitamin C 분석은 Hwang 등(23)의 방법을 변형하여 실시 하였다. Vitamin C 분석을 위한 시료 추출은 시료 $0.5 \mathrm{~g}$ 을 $5 \%$ metaphosphoric acid로 추출한 후 $4^{\circ} \mathrm{C}, 10,000 \mathrm{rpm}$ 에서 10 분간 원심분리 한 뒤 여과하여 $50 \mathrm{~mL}$ 로 정용한 것을 사용하였다. 추출액을 $0.45 \mu \mathrm{m}$ membrane filter로 여과한 뒤 HPLC로 분석하였다. HPLC 분석 조건으로 Column은

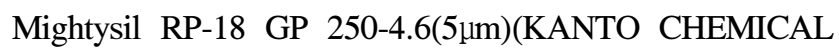
Co., Inc., Tokyo, Japan), 용매는 $0.1 \%$ trifluoroacetic $\operatorname{acid(Sigma~Co.),~flow~rateㄴㅡㄴ~} 0.6 \mathrm{~mL} / \mathrm{min}$ 이었고, 검출기는 UV detector(Waters, Milford, MA, USA)로 $254 \mathrm{~nm}$ 에서 측정 하였다.

\section{Total polyphenols 및 Flavonoids}

총 폴리페놀 및 폴라보노이드 함량 측정을 위한 시료 추출은 hesperidin 및 naringin 시료 추출방법과 동일한 방법 을 이용하였다. 총 폴리페놀은 Dewanto 등(24)의 방법에 따라 Folin-Ciocalteu reagent가 추출물의 폴리페놀성 화합 물에 의해 환원된 결과 몰리브덴 청색으로 발색하는 것을 원리로 분석하였다. 시료 추출물 $200 \mu \mathrm{L}$ 와 $2 \% \mathrm{Na}_{2} \mathrm{Co}_{3}$ 용액 $2 \mathrm{~mL}$ 을 가하여 2분간 방치하였다. $1 \mathrm{~N}$ Folin-Ciocalteu reagent $200 \mu \mathrm{L}$ 를 넣고 30 분간 암반응 시킨 후 $750 \mathrm{~nm}$ 에서 흡광도를 측정하였다. 이 때 표준물질로는 garlic acid를 사 용하여 검량선을 작성한 후 총 폴리페놀 함량은 시료 100 $\mathrm{g}$ 중 $\mathrm{mg}$ garlic acid로 나타내었다. 총 플라보노이드 함량은 $\mathrm{Jia}$ 등(25)의 방법을 이용하여 실험하였다. 시료 추출물 250 $\mu \mathrm{L}$ 에 증류수 $1 \mathrm{~mL}$ 을 넣고 $5 \% \mathrm{NaNo}_{2} 75 \mu \mathrm{L}$ 를 넣어 5 분간 반응시켰다. 그 뒤 $10 \% \mathrm{AlCl}_{3} \mathrm{H}_{2} \mathrm{O} 150 \mu \mathrm{L}$ 를 6분간 반응 시킨 후 $1 \mathrm{M} \mathrm{NaOH} 500 \mu \mathrm{L}$ 를 넣어 11 분간 반응시켜 510 $\mathrm{nm}$ 에서 흡광도를 측정하였다. 표준물질은 catechin hydrate 로 검량선을 작성 후 시료 $100 \mathrm{~g}$ 중의 $\mathrm{mg}$ catechin hydrate로 나타내었다.

\section{$\mathrm{DPPH}$ 라디컬 소거능}

시료 추출은 시료 $1 \mathrm{~g}$ 에 $200 \mathrm{~mL}$ 메탄올을 넣고 30분간 sonication에서 추출한 후 여과하여 농축한 뒤 $50 \mathrm{~mL}$ 로 정용 하였다. DPPH 라디컬 소거능은 Blois(26)의 방법을 변형하 여 측정하였다. 에탄올에 용해시킨 $1.5 \times 10^{-4} \mathrm{mM} \mathrm{DPPH}$ (2,2-diphenyl- $\beta$-picrylhydrazyl) 용액 $300 \mu \mathrm{L}$ 와 시료 추출액 $900 \mu \mathrm{L}$ 을 혼합 후 암실에서 30 분 동안 반응시켜 분광광도계 (PR-101a, Atago Co., Ltd., Tokyo, Japan)를 이용하여 530 $\mathrm{nm}$ 에서 흡광도를 측정하였다. DPPH 라디컬 소거능은 아 래의 식에 따라 산출하였다.

$\mathrm{DPPH}$ ridical 소거능 $(\%)=\left(1-\frac{\text { 시료 처리구의 흡광도 }}{\text { 시료 무첨가구의 흡광도 }}\right) \times 100$

\section{ABTS 라디컬 소거능}

$\mathrm{ABTS}$ 라디컬 소거능은 $\operatorname{Re}$ 등(27)의 방법을 변형하여 측정하였다. 시료 추출은 DPPH 라디컬 소거능 측정을 위한 시료 추출과 동일한 방법으로 실시하였다. $7 \mathrm{mM} \mathrm{ABTS}$ (2,2-azino-bis-(3-ethylbenzothiazoline-6-sulphonic acid)와 $2.45 \mathrm{mM}$ potassium persulfate를 하루 동안 암소에 방치하여 양이온을 형성시킨 후 실험 전 이 용액의 흡광도 값이 0.62-0.72가 되도록 희석하였다. 시료 추출액 $20 \mu \mathrm{L}$ 와 ABTS 용액 $180 \mu \mathrm{L}$ 를 가하여 섞은 후 $732 \mathrm{~nm}$ 에서 흡광도를 측정하 였다.

$\mathrm{ABTS}$ radical 소거능 $(\%)=\left(1-\frac{\text { 시료 처리구의 흡광도 }}{\text { 시료 무첨가구의 흡광도 }}\right) \times 100$

\section{통계처리}

모든 실험에서 3회 이상 반복한 결과를 SPSS(Statistical Package for Social Science 18.0, Chicago, IL, USA) 프로그램 을 이용하여 평균값과 표준편차를 나타내었다. 시료간의 유의성 검정은 one-way ANOVA를 한 후, $\mathrm{p}<0.05$ 수준에서 Duncan's multiple range test를 실시하여 유자 종류 및 부위 에 따른 시료간의 유의적인 차이를 비교하였다.

\section{결과 및 고찰}

\section{일반성분}

유자 종류 및 부위에 따른 일반성분을 분석한 결과는 Table 1에 나타내었다. 유자 종류에 따른 수분함량은 일반 유자에서는 씨가 $2.48 \%$ 를 나타내었으며 씨에 비하여 과육 의 수분함량은 유의적으로 낮은 $2.43 \%$ 를 나타내었다 $(\mathrm{p}<0.05)$. 유기농 유자 과피 및 과육은 각각 $3.48 \%$ 및 $3.47 \%$ 로 유기농 유자 씨 $(2.47 \%)$ 에 비하여 유의적으로 높은 수분 함량을 나타내었다 $(\mathrm{p}<0.05)$. 무농약 유자는 유기농 유자와 
유사한 결과를 나타내어 과피(3.51\%) 및 과육(3.55\%)에 비 하여 무농약 유자 씨가 $2.45 \%$ 로 낮은 수분함량을 나타내었 다( $\mathrm{p}<0.05)$.

유자의 부위별 수분함량은 과피, 과육 및 씨 등의 세 부위 중 씨에서 비교적 낮은 수분함량을 나타내었다. 과피 중 일반 과피는 유기농 과피 및 무농약 과피에 비하여 유의적 으로 낮은 수분함량을 나타내었으며( $\mathrm{p}<0.05)$, 유기농 과피 와 무농약 과피 간의 유의적 차이는 보이지 않았다. 과육의 경우 과피와 유사한 결과로 일반 과육은 $2.43 \%$ 로 유기농 과육(3.47\%) 및 무농약 과육(3.55\%)에 비하여 유의적으로 낮은 수분함량을 보였으며( $\mathrm{p}<0.05)$, 유기농 과육과 무농약 과육 간의 유의차는 보이지 않았다. 씨의 수분함량은 시료 간의 유의적 차이를 나타내지 않았다.

조단백에서는 일반 유자의 씨가 $16.37 \%$ 로 과피 $(5.94 \%)$ 와 과육(7.00\%)에 비하여 유의적으로 높은 함량을 나타내 었다(p<0.05). 유기농 및 무농약 유자도 일반 유자와 유사한 결과로 씨가 과피 및 과육에 비하여 높은 조단백 함랑을 보였으며 특히 유기농 및 무농약 씨는 일반 씨(16.37\%)에 비하여 유의적으로 높은 조단백 함량을 나타내었다 ( $<<0.05)$. 과육에서는 일반 과육이 $7.00 \%$ 로 유기농 과육 (6.18\%)에 비하여 유의적으로 높은 조단백 함량을 나타내 었으나(p<0.05), 무농약 과육(6.25\%)과는 유의차를 보이지 않았다. 유기농 과육 또한 무농약 과육과 유의적 차이를 나타내지 않았다. 과피에서는 유기농 과피가 $7.01 \%$ 로 일반

Table 1. Proximate composition of various parts of yuza depending on cultivation methods

$(\%)$

\begin{tabular}{|c|c|c|c|c|}
\hline & \multirow{2}{*}{ Parts } & \multicolumn{3}{|c|}{ Sample } \\
\hline & & General & Organic & Pesticide-free \\
\hline \multirow{3}{*}{ Moisture } & Peel & $2.45 \pm 0.01^{1 / \mathrm{ab} 2 \mathrm{~B} 33)}$ & $3.48 \pm 0.03^{\mathrm{aA}}$ & $3.51 \pm 0.25^{\mathrm{aA}}$ \\
\hline & Pulp & $2.43 \pm 0.02^{\mathrm{bB}}$ & $3.47 \pm 0.15^{\mathrm{aA}}$ & $3.55 \pm 0.05^{\mathrm{aA}}$ \\
\hline & Seed & $2.48 \pm 0.03^{\mathrm{aNS} 4)}$ & $2.47 \pm 0.01^{\mathrm{b}}$ & $2.45 \pm 0.01^{b}$ \\
\hline \multirow{3}{*}{ Crude protein } & Peel & $5.94 \pm 0.05^{\mathrm{bB}}$ & $7.01 \pm 0.06^{\mathrm{bA}}$ & $5.76 \pm 0.20^{\mathrm{CB}}$ \\
\hline & Pulp & $7.00 \pm 0.02^{\mathrm{bA}}$ & $6.18 \pm 0.02^{\mathrm{cB}}$ & $6.25 \pm 0.01^{\mathrm{bC}}$ \\
\hline & Seed & $16.37 \pm 1.24^{\mathrm{aB}}$ & $17.91 \pm 0.30^{\mathrm{aA}}$ & $18.19 \pm 0.01^{\mathrm{aA}}$ \\
\hline \multirow{3}{*}{ Crude fat } & Peel & $1.83 \pm 0.13^{\mathrm{cB}}$ & $2.42 \pm 0.13^{\mathrm{cA}}$ & $2.34 \pm 0.31^{\mathrm{bA}}$ \\
\hline & Pulp & $3.02 \pm 0.06^{\mathrm{bC}}$ & $4.81 \pm 0.10^{\mathrm{bA}}$ & $3.21 \pm 0.06^{\mathrm{bB}}$ \\
\hline & Seed & $30.10 \pm 0.6 \mathrm{1}^{\mathrm{aNS}}$ & $31.51 \pm 0.74^{\mathrm{a}}$ & $30.53 \pm 1.01^{\mathrm{a}}$ \\
\hline \multirow{3}{*}{ Crude ash } & Peel & $2.96 \pm 0.09^{\mathrm{bA}}$ & $2.80 \pm 0.02^{\mathrm{bB}}$ & $3.10 \pm 0.10^{\mathrm{bA}}$ \\
\hline & Pulp & $4.61 \pm 0.06^{\mathrm{aA}}$ & $4.37 \pm 0.10^{\mathrm{aB}}$ & $4.39 \pm 0.07^{\mathrm{aB}}$ \\
\hline & Seed & $2.41 \pm 0.21^{\mathrm{cB}}$ & $2.82 \pm 0.12^{\mathrm{bA}}$ & $2.76 \pm 0.02^{\mathrm{cA}}$ \\
\hline
\end{tabular}

\footnotetext{
${ }^{1)}$ All values are mean $\pm \mathrm{SD}(\mathrm{n}=3)$.

${ }^{2)-c}$ Means with different superscripts in the same column are significantly different at $\mathrm{p}<0.05$ by Duncan's multiple range test.

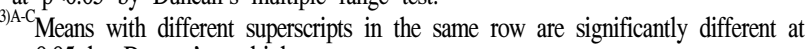
$\mathrm{p}<0.05$ by Duncan's multiple range test.

${ }^{4)} \mathrm{NS}$, not significant.
}

과피와 무농약 과피에 비하여 높은 조단백 함량을 보였으며 $(\mathrm{p}<0.05)$, 일반 과피와 무농약 과피는 서로간의 유의차를 나타내지 않았다.

일반, 유기농 및 무농약 유자의 조지방 함량은 조단백 함량과 유사한 경향을 보였고, 과피와 과육에 비하여 씨가 지방 함량이 높은 것으로 나타났으며, 씨의 지방 함량은 재배방식에 따른 유의적 차이를 나타내지 않았다. 씨 다음 으로 지방함량이 높은 부위는 과육으로 유기농 과육이 $4.81 \%$ 로 일반 과육(3.02\%)과 무농약 과육(3.21\%)에 비하여 높은 조지방 함량을 나타내었다( $<<0.05)$. 과피에서는 일반 과피 $(1.83 \%)$ 가 유기농 과피(2.42\%)와 무농약 과피(2.34\%) 에 비하여 유의적으로 낮은 조지방 함량을 보였으며 유기농 과피와 무농약 과피 간의 유의적 차이는 없었다.

일반 유자의 조회분 함량은 과피, 과육 및 씨가 각각 $2.96 \%, 4.61 \%, 2.41 \%$ 로 시료간의 유의차를 나타내었으며 유기농 유자와 무농약 유자도 유사한 경향을 나타내었다 $(\mathrm{p}<0.05)$. 과피, 과육 및 씨 중 과육이 회분 함량이 많은 것으로 나타났으며, 과육 중 일반 과육은 $4.61 \%$ 로 유기농 과육(4.37\%)과 무농약 과육(4.39\%)에 비하여 유의적으로 높은 회분 함량을 보였다( $\mathrm{p}<0.05)$.

Hwang 등(23)은 개량종 유자 ( I, ㅍ) 과피와 재래종 유자 과피의 수분함량은 $80.5-81.5 \%$, 과즙의 수분함량은 $88.7-90.0 \%$ 로 시료간의 유의차를 보이지 않았으나, 조단백 은 재래종 과피(7.14\%)에 비하여 개량종(I)의 과피(8.19\%) 가 다소 높게 나타났다고 보고하였다. 또한 조회분의 경우 재래종 유자 과피는 $0.45 \%$ 로 개량종 유자 $(\mathrm{I}, \mathrm{II})$ 과피에 비하여 낮게 나타났고 재래종 유자 과즙 및 개량종 유자 (I) 과즙은 각각 $0.50 \%$ 및 $0.50 \%$ 로 개량종 유자() 과즙 $(0.60 \%)$ 에 비하여 낮은 조회분 함량을 나타내었다고 보고 하여 본 실험과 차이를 나타내었는데 이는 유자시료의 전처 리 조건이 다르기 때문으로 사료된다.

\section{유리당}

유자 종류 및 부위에 따른 유리당을 분석한 결과는 Table 2 와 같다. 유리당은 fructose, glucose, sucrose가 검출되었는 데 세 부위 중 과피의 유리당 함량은 fuctose $>$ glucose $>$ sucrose의 순이었다. 과육의 유리당 함량은 sucrose > fructose > glucose의 순이었으며 씨에 함유되어 있는 유리 당은 sucrose 뿐이었다.

일반 유자 과피의 fructose 함량은 $278.03 \mathrm{mg} / \mathrm{g}$ 으로 과육 $139.29 \mathrm{mg} / \mathrm{g}$ 에 비하여 유의적으로 높은 함량을 나타내었으 며 $(\mathrm{p}<0.05)$, 유기농 유자와 무농약 유자의 경우에도 일반 유자와 비슷한 결과로 과육의 fructose 함량이 과피에 비하 여 낮은 함량을 나타내었다. 과피 중 일반 과피는 278.03 $\mathrm{mg} / \mathrm{g}$ 으로 무농약 과피 $(196.73 \mathrm{mg} / \mathrm{g})$ 에 비하여 유의적으로 높은 fructose 함량을 보였으며(p<0.05), 유기농 과피(272.26 $\mathrm{mg} / \mathrm{g}$ )와는 유의차를 나타내지 않았다. 과육의 fructose 함량 
은 122.03-139.29 mg/g으로 유자 종류에 따른 시료간의 유 의차를 나타내지 않았다. 또한 glucose 함량도 유자 종류에 따른 시료간의 차이는 없었으며 부위에 중에서는 과피가 높은 것으로 나타났다. 일반 과피와 무농약 과피는 각각 $164.65 \mathrm{mg} / \mathrm{g}, 156.19 \mathrm{mg} / \mathrm{g}$ 의 값으로 무농약 과피(114.71 $\mathrm{mg} / \mathrm{g}$ )에 비하여 유의적으로 높은 glucose 함량을 나타내었 다 $(\mathrm{p}<0.05)$. 과육의 glucose 함량은 일반, 유기농 및 무농약 시료간의 차이를 보이지 않았다.

유자의 sucrose 함량은 일반 과육이 $220.17 \mathrm{mg} / \mathrm{g}$ 으로 과 피 $(99.74 \mathrm{mg} / \mathrm{g})$ 와 씨 $(78.94 \mathrm{mg} / \mathrm{g})$ 에 비하여 유의적으로 높 은 함량을 나타내었다( $\mathrm{p}<0.05)$. 유기농 유자와 무농약 유자 또한 과육이 각각 $148.16 \mathrm{mg} / \mathrm{g}, 208.24 \mathrm{mg} / \mathrm{g}$ 로 과피와 씨에 비하여 높은 sucrose 함량을 보였다. 이처럼 sucrose는 과육 에 많이 함유되어 있는데 과육 중 일반 과육과 무농약 과육 이 각각 $220.17 \mathrm{mg} / \mathrm{g}, 208.24 \mathrm{mg} / \mathrm{g}$ 으로 유기농 과육(148.16 $\mathrm{mg} / \mathrm{g}$ )에 비하여 유의적으로 높은 함량을 나타내었다 $(p<0.05)$. 과피와 씨의 sucrose 함량은 비슷한 수준이었는데 과피 중 일반 과피는 $99.74 \mathrm{mg} / \mathrm{g}$ 으로 유기농 과피(67.16 $\mathrm{mg} / \mathrm{g})$ 와 무농약 과피 $(78.84 \mathrm{mg} / \mathrm{g})$ 에 비하여 유의적으로 높 은 함량을 나타내었다( $<<0.05)$. 씨는 일반, 유기농 및 무농 약 씨가 각각 $78.94 \mathrm{mg} / \mathrm{g}, 81.48 \mathrm{mg} / \mathrm{g}, 79.44 \mathrm{mg} / \mathrm{g}$ 으로 시료 간의 유의차를 나타내지 않았다.

Lee 등(2)의 연구에서는 유자 중 유리당이 fructose, glucose 및 sucrose로 검출되었으며, fructose와 glucose는 과피에, sucrose는 과육에서 높은 함량을 보여 본 연구와 유사한 결과를 나타내었다. 그러나 유자 중 총 유리당 함량

Table 2. Free sugar content of various parts of yuza depending on cultivation methods

$(\mathrm{mg} / \mathrm{g})$

\begin{tabular}{|c|c|c|c|c|}
\hline & \multirow{2}{*}{ Parts } & \multicolumn{3}{|c|}{ Sample } \\
\hline & & General & Organic & Pesticide-free \\
\hline \multirow{3}{*}{ Fructose } & Peel & $278.03 \pm 21.56^{(1) 22) A 3)}$ & $272.26 \pm 16.11^{\mathrm{aA}}$ & $196.73 \pm 6.83^{\mathrm{aB}}$ \\
\hline & Pulp & $139.29 \pm 4.44^{\mathrm{bNS} 4)}$ & $122.03 \pm 8.50^{\mathrm{b}}$ & $136.70 \pm 22.10^{\mathrm{b}}$ \\
\hline & Seed & $\mathrm{ND}^{5)}$ & ND & ND \\
\hline \multirow{3}{*}{ Glucose } & Peel & $164.65 \pm 8.53^{\mathrm{aA}}$ & $156.19 \pm 4.51^{\mathrm{aA}}$ & $114.71 \pm 0.72^{\mathrm{aB}}$ \\
\hline & Pulp & $64.74 \pm 2.18^{\mathrm{bNS}}$ & $54.78 \pm 1.90^{\mathrm{b}}$ & $63.59 \pm 9.25^{\mathrm{b}}$ \\
\hline & Seed & ND & ND & ND \\
\hline \multirow{3}{*}{ Sucrose } & Peel & $99.74 \pm 4.85^{\mathrm{bA}}$ & $67.16 \pm 2.55^{\mathrm{cC}}$ & $78.84 \pm 0.95^{\mathrm{bB}}$ \\
\hline & Pulp & $220.17 \pm 16.58^{\mathrm{aA}}$ & $148.16 \pm 7.04^{\mathrm{aB}}$ & $208.24 \pm 41.10^{\mathrm{aA}}$ \\
\hline & Seed & $78.94 \pm 4.45^{\mathrm{cNS}}$ & $81.48 \pm 2.64^{b}$ & $79.44 \pm 3.34^{\mathrm{b}}$ \\
\hline
\end{tabular}

\footnotetext{
${ }^{1)}$ All values are mean \pm SD $(n=3)$.

${ }^{2) a-c}$ Means with different superscripts in the same column are significantly different at $p<0.05$ by Duncan's multiple range test.

3)A-C Means with different superscripts in the same row are significantly different at $\mathrm{p}<0.05$ by Duncan's multiple range test.

${ }^{4} \mathrm{NS}$, not significant.

${ }^{5} \mathrm{ND}$, not detected.
}

이 8.44-12.19 g/100 g의 범위로 산지에 따른 유의차를 나타 내었다고 보고하였으며, 특히 고흥 및 남해산 유자 과피의 fructose는 $4.0 \mathrm{~g} / 100 \mathrm{~g}$ 이상으로 나타났으며, 고흥 및 남해 개량종 유자가 재래종에 비하여 다소 높은 유리당 함량을 나타내었다고 보고하였다. 반면 Kang 등(4)은 유자의 유리 당이 과피(6.22\%)보다 과육 $(9.80 \%)$ 에 더 많이 함유 되어 있는 것으로 보고하여 본 실험과 상이한 결과였다. 본 연구 에서 다른 연구 결과에 비하여 높은 유리당 함량을 나타낸 것은 시료 전처리 과정의 차이 때문인 것으로 생각된다.

\section{유기산}

유자 종류 및 부위에 따른 유기산을 분석한 결과는 Table 3 에 나타내었다. 유기산은 oxalic acid, citric acid, malic acid, succinic acid, fumaric acid가 검출되었다.

Oxalic acid를 분석한 결과 일반 유자 과육은 과피와 씨에 비하여 유의적으로 가장 많은 함량을 나타내었다( $\mathrm{p}<0.05)$. 유기농 유자는 과피와 과육이 각각 $10.38 \mu \mathrm{g} / \mathrm{g}, 7.20 \mu \mathrm{g} / \mathrm{g}$ 의 값으로 씨에 비하여 유의적으로 높은 oxalic acid 함량을 보였으며 무농약 유자는 일반 유자와 비슷한 결과를 나타내 었다. 부위에 따른 oxalic aicd 함량을 분석한 결과 유기농 과피는 $10.38 \mathrm{\mu g} / \mathrm{g}$ 으로 일반 과피 $(3.88 \mathrm{\mu g} / \mathrm{g})$ 와 무농약 과피 $(0.90 \mu \mathrm{g} / \mathrm{g})$ 에 비하여 유의적으로 높은 함량을 보였다 ( $\mathrm{p}<0.05)$. 과육의 oxalic acid 함량은 5.11-9.26 $\mu \mathrm{g} / \mathrm{g}$ 의 범위로 시료간의 유의차를 나타내지 않았다. 씨에서는 무농약 씨 가 $1.81 \mu \mathrm{g} / \mathrm{g}$ 으로 일반 $(1.52 \mu \mathrm{g} / \mathrm{g})$ 과 유기농 $(1.47 \mu \mathrm{g} / \mathrm{g}$ )에 비하여 유의적으로 높은 함량을 보였으며 $(\mathrm{p}<0.05)$, 일반 씨 와 유기농 씨는 유의차를 나타내지 않았다.

일반 유자에서의 citric acid 함량은 과육이 $120.60 \mathrm{\mu g} / \mathrm{g}$ 으 로 과피 $(26.83 \mu \mathrm{g} / \mathrm{g})$ 및 씨 $(3.37 \mathrm{\mu g} / \mathrm{g})$ 에 비하여 유의적으로 가장 높은 함량을 보였으며, 유기농 유자와 무농약 유자에 서도 유사한 결과를 나타내었다. 과피, 과육 및 씨 부위 중 과육에서 citric acid 함량이 높은 것으로 나타났으며, 과육 중 유기농 과육이 $131.26 \mu \mathrm{g} / \mathrm{g}$ 으로 유의적으로 가장 높은 함량을 나타내었다 $(\mathrm{p}<0.05)$. 유기농 과육은 일반 과육 $(120.60 \mu \mathrm{g} / \mathrm{g})$ 과 무농약 과육 $(106.69 \mathrm{\mu g} / \mathrm{g})$ 과 유의차를 나타 내었다(p<0.05). 과피는 일반 과피가 $26.83 \mu \mathrm{\mu g} / \mathrm{g}$ 으로 유기농 과피와 무농약 과피에 비하여 유의적으로 높은 citric acid 함량을 보였으며, 씨에서는 3.37-3.69 $\mathrm{\mu g} / \mathrm{g}$ 으로 유자 종류에 따른 시료간의 유의차를 나타내지 않았다.

일반 유자의 malic acid를 분석한 결과, malic acid는 일반 유자 과육에 많이 함유되어 있는 것으로 나타났으며 5.98 $\mathrm{\mu g} / \mathrm{g}$ 의 값으로 과피 $(4.97 \mu \mathrm{g} / \mathrm{g})$ 와 씨 $(1.10 \mu \mathrm{g} / \mathrm{g})$ 에 비하여 유의적으로 높은 함량을 나타내었다( $\mathrm{p}<0.05)$. 유기농 유자 과피와 씨는 각각 $3.52 \mathrm{\mu g} / \mathrm{g}, 2.21 \mathrm{\mu g} / \mathrm{g}$ 으로 유기농 과피(5.88 $\mu \mathrm{g} / \mathrm{g})$ 에 비하여 유의적으로 낮은 함량을 보였으며 $(\mathrm{p}<0.05)$, 유기농 유자 과피와 씨 간의 유의차는 나타내지 않았다. 무농약 유자 씨는 $1.04 \mu \mathrm{g} / \mathrm{g}$ 으로 무농약 과피 $(4.16 \mu \mathrm{g} / \mathrm{g}$ )와 
무농약 과육 $(5.30 \mu \mathrm{g} / \mathrm{g})$ 에 비하여 유의적으로 낮은 malic acid 함량을 보였으며 무농약 과피와 과육간의 유의차는 나타나내지 않았다. Malic acid를 부위별로 분석한 결과, 과육에 많이 함유되어 있었는데 일반, 유기농 및 무농약은 $5.30-5.98 \mathrm{\mu g} / \mathrm{g}$ 의 범위로 시료간의 유의적 차이를 보이지 않았다.

Succinic acid를 분석한 결과 일반 유자에서는 과피와 씨 에 비하여 과육 $(7.73 \mu \mathrm{g} / \mathrm{g})$ 에 많이 함유되어 있는 것으로 나타났으며, 유기농 유자와 무농약 유자도 유사한 결과를 보였다. Succinic acid는 malic acid와 유사한 결과로 세 부위 중 과육에 많이 함유되어 있는 것으로 나타났는데 과육 중 succinic aicd 함량은 7.00-7.73 $\mu \mathrm{g} / \mathrm{g}$ 으로 유자 종류에 따른 유의차를 보이지 않았다.

Fumaric acid는 세 부위 중 씨에서 높게 나타났으며, 과육 에는 함유되어 있지 않은 것으로 나타났다. 씨 중 유기농 씨가 $12.68 \mu \mathrm{g} / \mathrm{g}$ 으로 유의적으로 가장 높은 함량을 보였고 일반 씨와 무농약 씨는 시료간의 유의차를 보이지 않았다. 과피 중 일반 과피는 $1.23 \mathrm{\mu g} / \mathrm{g}$ 으로 유기농 과피 $(2.31 \mathrm{\mu g} / \mathrm{g})$ 와 무농약 과피 $(2.27 \mathrm{\mu g} / \mathrm{g})$ 에 비하여 유의적으로 낮은 fumaric aicd 함량을 나타내었으며 $(\mathrm{p}<0.05)$, 씨와 마찬가지

Table 3. Organic acid content of various parts of yuza depending on cultivation methods

(ug/g)

\begin{tabular}{|c|c|c|c|c|}
\hline & \multirow{2}{*}{ Parts } & \multicolumn{3}{|c|}{ Sample } \\
\hline & & General & Organic & Pesticide-free \\
\hline \multirow{3}{*}{ Oxalic } & Peel & $3.88 \pm 0.38^{1 / 202 / B 3}$ & $10.38 \pm 3.16^{\mathrm{aA}}$ & $0.90 \pm 0.05^{\mathrm{bC}}$ \\
\hline & Pulp & $9.26 \pm 6.08^{\mathrm{aNS} 4)}$ & $7.20 \pm 2.35^{\mathrm{a}}$ & $5.11 \pm 0.90^{\mathrm{a}}$ \\
\hline & Seed & $1.52 \pm 0.11^{\mathrm{cB}}$ & $1.47 \pm 0.11^{\mathrm{bB}}$ & $1.81 \pm 0.14^{\mathrm{bA}}$ \\
\hline \multirow{3}{*}{ Citric } & Peel & $26.83 \pm 0.90^{\mathrm{bA}}$ & $18.58 \pm 1.09^{\mathrm{bB}}$ & $19.18 \pm 2.14^{\mathrm{bB}}$ \\
\hline & Pulp & $120.60 \pm 2.93^{\mathrm{aAB}}$ & $131.26 \pm 3.97^{\mathrm{aA}}$ & $106.69 \pm 15.18^{\mathrm{aB}}$ \\
\hline & Seed & $3.37 \pm 1.13^{\mathrm{cNS}}$ & $3.60 \pm 0.14^{\mathrm{c}}$ & $3.69 \pm 0.10^{\mathrm{b}}$ \\
\hline \multirow{3}{*}{ Malic } & Peel & $4.97 \pm 0.16^{\mathrm{bA}}$ & $3.52 \pm 0.16^{6 \mathrm{~B}}$ & $4.16 \pm 0.85^{\mathrm{aAB}}$ \\
\hline & Pulp & $5.98 \pm 0.82^{\text {aNS }}$ & $5.88 \pm 0.59^{\mathrm{a}}$ & $5.30 \pm 0.83^{\mathrm{a}}$ \\
\hline & Seed & $1.10 \pm 0.16^{\mathrm{cNS}}$ & $2.21 \pm 1.12^{\mathrm{b}}$ & $1.04 \pm 0.03^{b}$ \\
\hline \multirow{3}{*}{ Succinic } & Peel & $3.49 \pm 0.14^{\mathrm{bB}}$ & $5.11 \pm 0.32^{\mathrm{bA}}$ & $2.88 \pm 0.09^{\mathrm{bC}}$ \\
\hline & Pulp & $7.73 \pm 0.28^{\mathrm{aNS}}$ & $7.00 \pm 0.33^{\mathrm{a}}$ & $7.25 \pm 1.10^{\mathrm{a}}$ \\
\hline & Seed & $0.68 \pm 0.59^{\mathrm{cB}}$ & $1.72 \pm 0.14^{\mathrm{cA}}$ & $1.00 \pm 0.01^{\mathrm{cB}}$ \\
\hline \multirow{3}{*}{ Fumaric } & Peel & $1.23 \pm 0.01^{\mathrm{bB}}$ & $2.31 \pm 0.06^{\mathrm{bA}}$ & $2.27 \pm 0.12^{\mathrm{bA}}$ \\
\hline & Pulp & $\mathrm{ND}^{5)}$ & ND & ND \\
\hline & Seed & $11.47 \pm 0.24^{\mathrm{aB}}$ & $12.68 \pm 0.59^{\mathrm{aA}}$ & $11.20 \pm 0.39^{\mathrm{aB}}$ \\
\hline
\end{tabular}

${ }^{1)}$ All values are mean $\pm \mathrm{SD}(\mathrm{n}=3)$.

${ }^{2) a-c}$ Means with different superscripts in the same column are significantly different at $\mathrm{p}<0.05$ by Duncan's multiple range test.

${ }^{3) A-C}$ Means with different superscripts in the same row are significantly different at $p<0.05$ by Duncan's multiple range test.

${ }^{4} \mathrm{NS}$, not significant.

${ }^{5} \mathrm{ND}$, not detected.
로 유기농 과피와 무농약 과피는 시료간의 유의적 차이를 보이지 않았다.

Shin 등(3)의 유자 연구에서는 유자의 과피와 과육에서 malonic acid, malic acid, citric acid 및 succinic acid가 검출되 었으며 그 중 citric acid가 10.2-17.7 g/100 g으로 기타 유기산 에 비하여 가장 높은 함량을 나타내었다고 보고하였다. 또 한 Kang 등(4)은 국내산 유자의 부위별 유기산을 분석한 결과 총 6 종을 확인하였고 과육과 과피에 citric acid가 가장 높은 함량을 나타내었다고 보고하였다. 본 실험 결과 citric acid가 유자의 주된 유기산이며 유자의 종류와 부위의 차이 는 유자에 함유되어 있는 유기산의 종류 및 함량에 영향을 미치는 것으로 보인다.

\section{Hesperidin 및 Naringin}

유자 종류 및 부위에 따라 hesperidin 함량을 분석한 결과 는 Table 4와 같다. 유자 종류에 따른 hesperidin 함량은 일반 유자 과피는 $12.94 \mathrm{mg} / \mathrm{g}$ 으로 과육 $(4.42 \mathrm{mg} / \mathrm{g})$ 과 씨 $(1.98 \mathrm{mg} / \mathrm{g})$ 에 비하여 유의적으로 높은 함량을 나타내었다 ( $\mathrm{p}<0.05)$. 유기농 유자와 무농약 유자 또한 일반 유자와 유 사한 결과로 과피에 hesperidin 함량이 높고 씨에서 낮은 함량을 나타내는 것으로 보였다. 유자의 과피 중 유기농 과피는 $12.03 \mathrm{mg} / \mathrm{g}$ 으로 일반 과피 $(12.94 \mathrm{mg} / \mathrm{g})$ 와 무농약 과피 $(13.23 \mathrm{mg} / \mathrm{g})$ 에 비하여 유의적으로 낮은 hesperidin 함 량을 나타내었으며 $(\mathrm{p}<0.05)$, 일반 과피와 무농약 과피는 시 료간의 유의차를 보이지 않았다.

과육 중 무농약 과육의 hesperidin 함량은 $6.21 \mathrm{mg} / \mathrm{g}$ 으로 나타났으며 일반 과육 $(4.42 \mathrm{mg} / \mathrm{g})$ 과 유기농 과육 $(4.30 \mathrm{mg} / \mathrm{g})$ 에 비하여 유의적으로 높은 함량을 보였다( $<<0.05)$. 유기농 씨의 hesperidin 함량은 $2.22 \mathrm{mg} / \mathrm{g}$ 으로 일반 씨 $(1.97 \mathrm{mg} / \mathrm{g}$ )와 무농약 씨 $(2.88 \mathrm{mg} / \mathrm{g})$ 와 유의차를 나타내지 않았으나, 무농 약 씨는 일반씨에 비하여 유의적으로 높은 함량을 보였다 $(\mathrm{p}<0.05)$.

Table 4. Heperidin content of various parts of yuza depending on cultivation methods

\begin{tabular}{|c|c|c|c|c|}
\hline \multirow{2}{*}{ Parts } & \multicolumn{3}{|c|}{ Sample } & \multirow{2}{*}{ F-value } \\
\hline & General & Organic & Pesticide-free & \\
\hline Peel & $12.94 \pm 0.55^{1 \mathrm{la2} 2 \mathrm{~A} 3)}$ & $12.03 \pm 0.61^{\mathrm{aB}}$ & $13.23 \pm 0.65^{\mathrm{aA}}$ & $6.432^{*}$ \\
\hline Pulp & $4.42 \pm 0.63^{\mathrm{bB}}$ & $4.30 \pm 0.47^{\mathrm{bB}}$ & $6.21 \pm 0.73^{\mathrm{bA}}$ & $17.854^{* * *}$ \\
\hline Seed & $1.98 \pm 0.46^{\mathrm{BB}}$ & $2.22 \pm 0.30^{\mathrm{cAB}}$ & $2.88 \pm 0.90^{\mathrm{cA}}$ & $3.561^{\mathrm{NS} 4)}$ \\
\hline F-value & $657.794^{* * 55)}$ & $699.695^{\text {k*k }}$ & $283.467^{* * * *}$ & \\
\hline \multicolumn{5}{|c|}{$\begin{array}{l}{ }^{1)} \text { All values are mean } \pm \mathrm{SD}(\mathrm{n}=3) \text {. } \\
\text { 2)a-c Means with different superscripts in the same column are significantly different } \\
\text { at } \mathrm{p}<0.05 \text { by Duncan's multiple range test. } \\
\text { 3)A-C Means with different superscripts in the same row are significantly different at } \\
\text { p }<0.05 \text { by Duncan's multiple range test. } \\
\text { 4) NS, not significant. } \\
\text { 5)*** } p<0.001\end{array}$} \\
\hline
\end{tabular}


산지별 유자의 생리활성 연구(15)에서 과피 및 과육의 hesperidin 함량을 분석한 결과 과피의 heperidin 함량은 과 육에 비하여 약 4.81-7.80배 더 높게 정량되었다고 보고하였 으며, 고흥재래종 과피 $72.48 \mathrm{mg} / 100 \mathrm{~g}$, 고흥개량종 과피 $74.41 \mathrm{mg} / 100 \mathrm{~g}$, 고흥재래종 과육 $10.77 \mathrm{mg} / 100 \mathrm{~g}$, 고흥개량 종 과육 $11.24 \mathrm{mg} / 100 \mathrm{~g}$ 으로 고흥 개량종이 고흥 재래종에 비하여 비교적 높은 hesperidin 함량을 나타내었다고 보고 하였다.

Naringin의 함량을 측정한 결과는 Table 5 에 나타내었다. 유자 종류에 따른 naringin 함량은 hesperidin 함량 결과와 유사하였으며, 세 부위 중 과피에서 높은 함량을 나타내었 는데 그 중 일반 과피와 무농약 과피는 각각 $4.61 \mathrm{mg} / \mathrm{g}$, $4.44 \mathrm{mg} / \mathrm{g}$ 으로 유기농 과피 $(4.15 \mathrm{mg} / \mathrm{g})$ 에 비하여 유의적으 로 높은 naringin 함량을 나타내었다. 과육에서는 무농약 과육 $(3.13 \mathrm{mg} / \mathrm{g})$ 이 일반 과육 $(2.49 \mathrm{mg} / \mathrm{g})$ 과 유기농 과육 $(2.55 \mathrm{mg} / \mathrm{g})$ 에 비하여 유의적으로 높은 naringin 함량을 보 였으며 $(\mathrm{p}<0.05)$, 일반 과육과 유기농 과육 간의 유의차는 나타내지 않았다. 씨의 naringin 함량은 무농약 씨(1.46 $\mathrm{mg} / \mathrm{g})$ 와 유기농 씨 $(1.48 \mathrm{mg} / \mathrm{g}) \mathrm{rk}$ 일반 씨 $(1.28 \mathrm{mg} / \mathrm{g})$ 에 비해 유의적으로 높은 함량을 보였다.

Shin 등(15)은 유자 과육의 경우 heperidin 함량과 유사한 범위였으나 비교적 낮은 함량을 나타내었다고 보고하였으 며 고흥 개량종 과육의 경우 $9.84 \mathrm{mg} / 100 \mathrm{~g}$ 으로 다른 시료에 비하여 유의적으로 높은 함량을 나타내었다고 보고하였다. 또한 과피의 naringin 함량은 $28.69-44.96 \mathrm{mg} / 100 \mathrm{~g}$ 의 범위 로 정량되었다고 하였다. 이러한 시료간의 함량차이는 품 종, 재배조건, 재배지역 및 수확시기에 따른 조건이 서로 다르기 때문 인 것으로 보고하였으며, 감귤류 과피 내 hesperidin 함량은 과실이 성숙됨에 따라 점차 감소하여 당 유자는 9월-12월에 $11.66 \%$ 에서 $7.82 \%$ 로 감소된다고 하였 다(28). 본 실험 결과도 naringin의 함량이 hesperidin 함량에 비하여 낮은 함량을 나타내었다.

Table 5. Naringin content of various parts of yuza depending on cultivation methods

\begin{tabular}{|c|c|c|c|c|c|}
\hline & \multirow{2}{*}{ Parts } & \multicolumn{4}{|c|}{ Samples } \\
\hline & & General & Organic & Pesticide-free & F-value \\
\hline \multirow{3}{*}{ Naringin } & Peel & $4.61 \pm 0.29^{(\mathrm{l} / \mathrm{a} 2) \mathrm{A} 3 \mathrm{3})}$ & $4.15 \pm 0.29^{\mathrm{aB}}$ & $4.44 \pm 0.23^{\mathrm{aAB}}$ & $4.432^{*}$ \\
\hline & Pulp & $2.49 \pm 0.18^{\mathrm{bB}}$ & $2.55 \pm 0.31^{\mathrm{bB}}$ & $3.13 \pm 0.37^{\mathrm{bA}}$ & $8.346^{* *}$ \\
\hline & Seed & $1.28 \pm 0.17^{\mathrm{cB}}$ & $1.48 \pm 0.13^{\mathrm{cA}}$ & $1.46 \pm 0.14^{\mathrm{cA}}$ & $3.511^{\mathrm{NS} 4)}$ \\
\hline \multicolumn{2}{|c|}{ F-value } & $350.745^{* \star * 5)}$ & $164.427^{* * *}$ & $194.413^{* * *}$ & \\
\hline
\end{tabular}

${ }^{1)}$ All values are mean $\pm \mathrm{SD}(\mathrm{n}=3)$.

2)a-c Means with different superscripts in the same column are significantly different at $\mathrm{p}<0.05$ by Duncan's multiple range test.

3)A-C Means with different superscripts in the same row are significantly different at $\mathrm{p}<0.05$ by Duncan's multiple range test.

${ }^{4)} \mathrm{NS}$, not significant.

$5)^{* * *}, \mathrm{p}<0.001$
Table 6. Vitamin C content of various parts of yuza depending on cultivation methods

\begin{tabular}{ccccc} 
& & & $(\mathrm{mg} / 100 \mathrm{~g})$ \\
\hline \multirow{2}{*}{ Parts } & \multicolumn{3}{c}{ Sample } & F-value \\
\cline { 2 - 4 } & General & Organic & Pesticide-free & \\
\hline Peel & $150.26 \pm 2.68^{1 \mathrm{bb2C} 3)}$ & $770.02 \pm 7.22^{\mathrm{AA}}$ & $550.54 \pm 12.85^{\mathrm{aB}}$ & $3958.197^{* * *}$ \\
Pulp & $225.57 \pm 5.83^{\mathrm{aC}}$ & $349.52 \pm 7.43^{\mathrm{bA}}$ & $297.31 \pm 0.48^{\mathrm{bB}}$ & $398.661^{* * *}$ \\
Seed & $13.26 \pm 0.39^{\mathrm{cB}}$ & $11.27 \pm 0.85^{\mathrm{CC}}$ & $17.46 \pm 0.95^{\mathrm{cA}}$ & $50.357^{* * *}$ \\
\hline F-value & $\left.2518.626^{* * * 4}\right)$ & $12030.012^{* * *}$ & $3848.752^{* * *}$ & \\
\hline
\end{tabular}

${ }^{1)}$ All values are mean $\pm \mathrm{SD}(\mathrm{n}=3)$.

${ }^{2) a-c}$ Means with different superscripts in the same column are significantly different at $p<0.05$ by Duncan's multiple range test.

3)A-C Means with different superscripts in the same row are significantly different at $\mathrm{p}<0.05$ by Duncan's multiple range test.

, $p<0.001$

이와 같은 결과로 감귤류에서 가장 많이 존재한다고 알 려진 플라보노이드 화합물인 hesperidin과 naringin이 유자 의 과피에 가장 많이 함유되어 있는 것을 확인하였다. 따라 서 설탕에 절인 유자차 보다는 최근 소비트렌드에 부합하면 서도 과피를 그대로 이용할 수 있는 건강차로 소비될 수 있는 제품에 적용이 필요할 것으로 보인다.

\section{Vitamin C}

유자 종류 및 부위에 따라 vitamin $\mathrm{C}$ 를 정량 분석한 결과 는 Table 6 과 같다. 일반 유자의 vitamin C 함량은 과육이 $225.57 \mathrm{mg} / 100 \mathrm{~g}$ 의 값으로 과피와 씨에 비하여 유의적으로 높은 함량을 나타내었다 $(\mathrm{p}<0.05)$. 유기농 유자의 vitamin $\mathrm{C}$ 함량은 과피가 $770.08 \mathrm{mg} / 100 \mathrm{~g}$ 으로 과육(349.52 mg/100 $\mathrm{g})$ 과 씨 $(11.27 \mathrm{mg} / 100 \mathrm{~g})$ 에 비하여 유의적으로 높은 함량을 보였으며, 무농약 유자는 유기농 유자와 유사한 결과로 과 피의 vitamin $\mathrm{C}$ 함량이 $550.54 \mathrm{mg} / 100 \mathrm{~g}$ 을 나타내었다 ( $<<0.05)$.

Vitamin C 함량은 유자의 세 부위 중 과피에 비교적 많이 함유되어 있고 씨에 적게 함유되어 있는 것으로 나타나 유자 종류와 부위에 따라 함량차이를 나타내었다. 과피 중 유기농 과피는 $770.02 \mathrm{mg} / 100 \mathrm{~g}$ 으로 유의적으로 가장 높은 함량을 나타내었다 $(\mathrm{p}<0.05)$. 일반 과피 $(150.26 \mathrm{mg} / 100 \mathrm{~g})$ 와 무농약 과피 $(550.54 \mathrm{mg} / 100 \mathrm{~g})$ 는 유기농 과피에 비하여 유 의적으로 낮은 함량을 보였으며, 특히 일반 과피는 과육보 다도 낮은 vitamin $\mathrm{C}$ 함량을 나타내었다 $(\mathrm{p}<0.05)$.

과육 중에서는 유기농 과육이 $349.52 \mathrm{mg} / 100 \mathrm{~g}$ 으로 일반 과육 $(225.57 \mathrm{mg} / 100 \mathrm{~g})$ 과 무농약 과육 $(297.31 \mathrm{mg} / 100 \mathrm{~g})$ 에 비하여 유의적으로 높은 vitamin $\mathrm{C}$ 함량을 나타내었다 $(\mathrm{p}<0.05)$.

Shin 등(15)은 유자 과육 중 비타민 C 함량은 6.14-10.74 $\mathrm{mg} / 100 \mathrm{~g}$ 으로 그 중 고흥 개량종이 $10.74 \mathrm{mg} / 100 \mathrm{~g}$ 으로 높은 vitamin $\mathrm{C}$ 함량을 나타내었다고 보고하였다. 또한 과 
피의 vitamin C 함량은 $19.38-30.21 \mathrm{mg} / 100 \mathrm{~g}$ 으로 과육에 비하여 과피에 많은 양의 vitamin $\mathrm{C}$ 가 함유되어 있는 것으로 보고하였는데 이는 본 연구결과와 유사하였다.

Hwang 등(23)은 재래종 및 개량종 유자( I, ㅍ)의 과즙에 함유되어 있는 vitamin C가 각각 $29.6 \mathrm{mg} \%, 21.4 \mathrm{mg} \%, 22.2$ $\mathrm{mg} \%$ 로 재래종 유자과즙에 vitamin $\mathrm{C}$ 가 더 많이 함유되어 있는 것으로 보고하였다.

\section{Total polyphenols 및 Flavonoids}

총 폴리페놀과 총 플라보노이드 함량을 측정한 결과는 Table 7과 같다. 유자 종류에 따른 총 폴리페놀 함량은 일반 유자 과피가 $0.85 \mathrm{mg} / \mathrm{g}$ 으로 과육 $(0.09 \mathrm{mg} / \mathrm{g})$ 과 씨 $(0.10$ $\mathrm{mg} / \mathrm{g}$ )에 비하여 유의적으로 높은 함량을 나타내었다 ( $<<0.05)$. 유기농 유자는 과피가 $0.68 \mathrm{mg} / \mathrm{g}$ 으로 과육 $(0.12$ $\mathrm{mg} / \mathrm{g})$ 과 씨 $(0.14 \mathrm{mg} / \mathrm{g})$ 에 비하여 높은 함량을 보였으며, 무 농약 유자는 유기농 유자와 유사한 결과를 나타내었다 $(\mathrm{p}<0.05)$.

유자의 세 부위 중 과피가 높은 총 폴리페놀 함량을 나타 내었으며 과육과 과피는 비슷한 수준이었다. 일반 과피는 $0.85 \mathrm{mg} / \mathrm{g}$ 으로 시료 중 가장 높은 함량을 나타내었으며, 유기농 과피 $(0.68 \mathrm{mg} / \mathrm{g})$ 와 무농약 과피 $(0.76 \mathrm{mg} / \mathrm{g})$ 는 일반 과피에 비하여 유의적으로 낮은 함량을 보였다(p<0.05).

과육 중 일반 과육은 $0.09 \mathrm{mg} / \mathrm{g}$ 으로 유기농 과육 $(0.12$ $\mathrm{mg} / \mathrm{g})$ 과 무농약 과육 $(0.14 \mathrm{mg} / \mathrm{g})$ 에 비하여 유의적으로 낮은 total polyphenol 함량을 나타내었으며( $\mathrm{p}<0.05)$, 유기농 과육 과 무농약 과육은 시료간의 유의차를 보이지 않았다. 일반 씨의 총 폴리페놀 함량은 $0.10 \mathrm{mg} / \mathrm{g}$ 으로 유기농 씨 $(0.14$ $\mathrm{mg} / \mathrm{g})$ 와 무농약 씨 $(0.12 \mathrm{mg} / \mathrm{g})$ 에 비하여 유의적으로 낮은 함량을 보였다.

총 플라보노이드 함량은 일반, 유기농 및 무농약 유자 모두 비슷한 결과를 보였는데 세 부위 중 씨에서 가장 높은

Table 7. Total polyphenols and flavonoids content of various parts of yuza depending on cultivation methods

$(\mathrm{mg} / \mathrm{g})$

\begin{tabular}{ccccc}
\hline & Parts & \multicolumn{3}{c}{ Sample } \\
\cline { 3 - 5 } & & General & Organic & Pesticide-free \\
\hline \multirow{2}{*}{ Total } & Peel & $0.85 \pm 0.03^{1 / 22) \mathrm{A} 3)}$ & $0.68 \pm 0.02^{\mathrm{aC}}$ & $0.76 \pm 0.04^{\mathrm{aB}}$ \\
polyphenols & Pulp & $0.09 \pm 0.03^{\mathrm{bC}}$ & $0.12 \pm 0.00^{\mathrm{CB}}$ & $0.14 \pm 0.00^{\mathrm{bA}}$ \\
& Seed & $0.10 \pm 0.00^{\mathrm{bC}}$ & $0.14 \pm 0.01^{\mathrm{bA}}$ & $0.12 \pm 0.00^{\mathrm{bB}}$ \\
\hline \multirow{2}{*}{ Total } & Peel & $0.18 \pm 0.00^{\mathrm{BB}}$ & $0.18 \pm 0.00^{\mathrm{bB}}$ & $0.19 \pm 0.01^{\mathrm{bA}}$ \\
flavonoids & Pulp & $0.16 \pm 0.01^{\mathrm{bC}}$ & $0.17 \pm 0.00^{\mathrm{bB}}$ & $0.19 \pm 0.00^{\mathrm{bA}}$ \\
& Seed & $0.81 \pm 0.04^{\mathrm{aB}}$ & $0.82 \pm 0.07^{\mathrm{aB}}$ & $0.89 \pm 0.02^{\mathrm{aA}}$ \\
\hline
\end{tabular}

\footnotetext{
${ }^{1)}$ All values are mean $\pm \mathrm{SD}(\mathrm{n}=3)$.

${ }_{\text {2)acc }}$ Means with different superscripts in the same column are significantly different at $p<0.05$ by Duncan's multiple range test.

3)A-C Means with different superscripts in the same row are significantly different at $p<0.05$ by Duncan's multiple range test.
}

총 플라보노이드 함량을 나타내었다. 그 중 무농약 씨가 $0.89 \mathrm{mg} / \mathrm{g}$ 으로 일반 씨와 유기농 씨에 비하여 유의적으로 가장 높은 함량을 보였으며 $(\mathrm{p}<0.05)$, 일반 씨와 유기농 씨는 시료간의 유의차를 보이지 않았다.

과피의 총 플라보노이드 함량은 무농약 과피 $(0.19 \mathrm{mg} / \mathrm{g})$ 가 유의적으로 가장 높았으며 $(\mathrm{p}<0.05)$, 일반 과피와 유기농 과피는 시료간의 유의차를 나타내지 않았다.

Shin 등(15)의 연구에서는 유자 과피 중의 총 폴리페놀 함량이 과육에 비하여 2.86-4.15배 높게 나타났으며 총 플라 보노이드 함량은 총 폴리페놀 함량과 유사한 경향으로 과육 $(1.95-3.93 \mathrm{mg} / 100 \mathrm{~g})$ 이 과피 $(9.67-11.87 \mathrm{mg} / 100 \mathrm{~g})$ 에 비하여 낮은 총 플라보노이드 함량을 나타내었다고 보고하였다.

Hwang 등(23)의 연구에서도 유자 시료 간의 차이는 나타 나지 않았으나 과피에 함유되어 있는 총 폴리페놀 함량이 90-100 mg\%로 과즙(21-22 $\mathrm{mg} \%$ )보다 2.5배 많이 함유되어 있는 것으로 보고하였다.

\section{DPPH 라디컬 소거능 및 ABTS 라디컬 소거능}

$\mathrm{DPPH}$ 라디컬 소거능과 $\mathrm{ABTS}$ 라디컬 소거능을 분석한 결과는 Table 8 에 나타내었다.

일반 유자의 DPPH 라디컬 소거능은 일반 유자 과피가 $72.98 \%$ 로 과육(7.30\%)과 씨(27.87\%)에 비하여 유의적으로 가장 높은 소거능을 나타내었으며( $\mathrm{p}<0.05)$, 유기농 유자와 무농약 유자에서도 유사한 결과를 보였다. DPPH 라디컬 소거능은 유자의 세 부위 중 과피에서 비교적 높은 소거활 성을 보였는데 그 중 무농약 과피와 일반 과피가 각각 $73.94 \%, 72.98 \%$ 로 유기농 과피(52.97\%)에 비하여 유의적 으로 높은 라디컬 소거활성을 나타내었다( $\mathrm{p}<0.05)$.

과피 다음으로 DPPH 라디컬 소거능이 높은 부위는 씨었 으며 유기농 씨와 무농약 씨는 각각 $36.76 \%, 36.65 \%$ 로 시료

Table 8. DPPH free radical scavenging activity (DPPH) and ABTS free radical scavenging activity (ABTS) of various parts of yuza depending on cultivation methods

$(\%)$

\begin{tabular}{ccccc}
\hline & & \multicolumn{3}{c}{ Sample } \\
\cline { 3 - 5 } & Parts & General & Organic & Pesticide-free \\
\cline { 3 - 5 } DPPH & Peel & $72.98 \pm 0.46^{1 \mathrm{la2}) \mathrm{A} 3)}$ & $52.97 \pm 0.65^{\mathrm{aB}}$ & $73.94 \pm 0.52^{\mathrm{aA}}$ \\
& Pulp & $7.30 \pm 1.65^{\mathrm{CNS} 4)}$ & $7.63 \pm 0.65^{\mathrm{c}}$ & $5.98 \pm 0.65^{\mathrm{c}}$ \\
& Seed & $27.87 \pm 1.44^{\mathrm{bB}}$ & $36.76 \pm 0.33^{\mathrm{bA}}$ & $36.65 \pm 0.06^{\mathrm{bA}}$ \\
\hline \multirow{4}{*}{ ABTS } & Peel & $84.04 \pm 0.85^{\mathrm{aA}}$ & $84.47 \pm 0.97^{\mathrm{aA}}$ & $77.90 \pm 0.37^{\mathrm{aB}}$ \\
& Pulp & $83.30 \pm 0.21^{\mathrm{aA}}$ & $82.07 \pm 1.06^{\mathrm{bB}}$ & $76.15 \pm 0.35^{\mathrm{bC}}$ \\
& Seed & $14.62 \pm 0.38^{\mathrm{bA}}$ & $13.53 \pm 0.58^{\mathrm{CB}}$ & $14.49 \pm 0.33^{\mathrm{cA}}$ \\
\hline
\end{tabular}

\footnotetext{
${ }^{1)}$ All values are mean $\pm \mathrm{SD}(\mathrm{n}=3)$.

${ }^{2)-C}$ Means with different superscripts in the same column are significantly different at $p<0.05$ by Duncan's multiple range test.

${ }^{3) A-C}$ Means with different superscripts in the same row are significantly different at $p<0.05$ by Duncan's multiple range test.

${ }^{4} \mathrm{NS}$, not significant.
} 
간의 유의적 차이를 나타내지 않았다. 일반 씨는 $27.87 \%$ 로 유기농 씨와 무농약 씨에 비하여 유의적으로 낮은 DPPH 라디컬 소거능을 보였다( $<<0.05)$.

과육 부분의 DPPH 라디컬 소거능은 5.98-7.63\%의 범위 로 유자 종류에 따른 유의차를 나타내지 않았다.

$\mathrm{ABTS}$ 라디컬 소거능을 분석한 결과, 일반 유자 과피와 과육이 각각 $84.04 \%, 83.30 \%$ 로 일반 유자 씨 $(14.62 \%)$ 에 비하여 유의적으로 높은 라디컬 소거능을 보였으며 $(\mathrm{p}<0.05)$, 과피와 과육은 시료간의 유의차를 나타내지 않았 다.

유기농 유자 과육의 $\mathrm{ABTS}$ 라디컬 소거능은 $82.07 \%$ 로 과피 $(84.47 \%)$ 에 비하여 유의적으로 낮은 소거능을 보였으 며, 유기농 유자 씨는 $13.53 \%$ 로 과피와 과육에 비하여 유의 적으로 낮은 소거활성을 나타내었다( $<<0.05)$. 무농약 유자 의 ABTS 라디컬 소거능은 유기농 유자와 유사한 결과를 나타내었다.

$\mathrm{ABTS}$ 라디컬 소거능에서도 DPPH 라디컬 소거능과 마 찬가지로 유자의 세 부위 중 과피에서 비교적 높은 소거능 을 나타내었다. 과피 중 유기농 과피는 $84.47 \%$ 로 무농약 과피(77.90\%)에 비하여 유의적으로 높은 소거능을 보였으 며 $(\mathrm{p}<0.05)$, 유기농 과피는 일반 과피 $(84.04 \%)$ 와 유의차를 나타내지 않았다. 과육에서는 일반 과육이 $83.30 \%$ 로 유기 농 과육(82.07\%)과 무농약 과육(76.15\%)에 비하여 유의적 으로 높은 소거능을 보였다( $<<0.05)$.

씨의 $\mathrm{ABTS}$ 라디컬 소거능은 일반 씨와 무농약 씨가 각각 $14.62 \%, 14.49 \%$ 의 값으로 유기농 씨(13.53\%)에 비하여 유 의적으로 높은 소거능을 나타내었다(p<0.05).

$\mathrm{Ji}$ 등(29)의 보고에 의하면 유자 과피 동결건조 분말의 물추출물의 항산화력은 총 폴리페놀 화합물의 함량과 상관 성이 있다고 하였으며, Cha와 $\mathrm{Cho(30)는} \mathrm{감귤류의} \mathrm{항산화}$ 활성은 플라보노이드의 역할이 크며 감귤류의 플라보노이 드를 분리하여 전자공여능을 실험한 결과 hesperidin이 naringin에 비하여 높은 항산화 활성을 나타냈다고 보고하 였다.

본 연구에서 총 폴리페놀 화합물은 과피에 많이 함유되 어 있었으며 총 플라보노이드 화합물은 씨에 많이 함유되어 있었는데 이는 본 실험의 전자공여능이 총 폴리페놀 화합물 뿐 아니라 플라보노이드 화합물의 영향을 받은 것으로 생각 된다.

\section{요 약}

유자 종류 및 부위에 따라 품질특성을 조사하기 위하여 일반성분, 유리당, 유기산, 비타민C, hesperidin 및 naringin 함량과 항산화 활성을 분석하였다. 유리당을 분석한 결과 총 3종(fructose, glucose, sucrose)이 검출되었는데 과피 중
유리당 함량은 fructose $>$ glucose $>$ sucrose 순이었으며, 과육 중 유리당 함량은 sucrose $>$ fructose $>$ glucose 순이었 다. 유자 씨에 함유되어 있는 유리당은 sucrose 뿐이었다.

유기산은 총 5종(oxalic acid, citric acid, malic acid, succinic acid, fumaric acid)이 검출되었는데 과피와 과육에 서는 citric acid가 높은 함량을 나타내었으며, 씨에서는 fumaric acid가 높은 함량을 나타내었다.

Hesperidin은 무농약 과피가 $13.23 \mathrm{mg} / \mathrm{g}$ 으로 가장 높은 함량을 나타내었으며, naringin은 세 부위 중 과피에서 높은 함량을 나타내었고 그 중 일반 과피 $(4.62 \mathrm{mg} / \mathrm{g})$ 가 가장 높은 함량을 나타내었다 $(\mathrm{p}<0.05)$.

Vitamin $\mathrm{C}$ 를 분석한 결과 다른 부위에 비하여 과피에 많이 함유되어 있었으며 종류 및 부위에 따라 유의적 차이 를 나타내었다(p<0.05). 유기농 과피는 $770.02 \mathrm{mg} / 100 \mathrm{~g}$ 으 로 유의적으로 가장 높은 vitamin C 함량을 나타내었고 씨 부분에 적게 함유되어 있는 것으로 분석되었다 $(\mathrm{p}<0.05)$.

총 폴리페놀 함량은 일반 과피가 $0.85 \mathrm{mg} / \mathrm{g}$ 의 값으로 가장 높은 함량을 나타내었으며, 무농약 과피와 유기농 과 피는 각각 $0.76 \mathrm{mg} / \mathrm{g}, 0.68 \mathrm{mg} / \mathrm{g}$ 으로 일반 과피에 비하여 유의적으로 낮은 함량을 나타내었다( $\mathrm{p}<0.05)$. 무농약 씨의 총 플라보노이드 함량은 $0.89 \mathrm{mg} / \mathrm{g}$ 으로 유자 시료 중 유의 적으로 가장 높은 함량을 나타내었으며 $(\mathrm{p}<0.05)$, 씨가 다른 부위에 비하여 높은 함량을 나타내었다. 일반, 유기농 및 무농약 과피와 과육 간 총 플라보노이드 함량은 유의차를 나타내지 않았다.

$\mathrm{DPPH}$ 라디컬 소거능에서는 세 부위 중 과피에서 비교적 높은 소거활성을 나타내었는데 그 중 무농약 과피가 $101.07 \%$ 로 가장 높은 소거활성을 나타내었다 $(\mathrm{p}<0.05)$. 과 피 다음으로 소거활성이 높은 부분은 씨로 $32.78-33.48 \%$ 의 값을 나타내었으며, 과육은 10.23-12.14\%를 나타내었다 (p<0.05). 유기농 과피의 ABTS 라디컬 소거능은 $84.47 \%$ 로 시료 중 유의적으로 높은 라디컬 소거능을 나타내었으며 $(\mathrm{p}<0.05)$, 일반 과피는 $84.04 \%$ 로 유기농 과피 $(84.47 \%)$ 와 일반 과육(83.30\%)과 유의차를 보이지 않았다. 씨의 경우 $13.53-14.62 \%$ 로 다른 부분에 비하여 유의적으로 낮은 소거 활성을 나타내었다 $(\mathrm{p}<0.05)$.

유자는 주로 과피 만을 이용한 유자차 형태로 많이 소비 되고 있어 과피를 제외한 나머지 부분들이 폐기되어 왔으 나, 본 실험 결과 유자 과피 외에 과육과 씨에도 많은 유용성 분이 함유되어 있으므로 유자 생과를 효율적으로 이용한 다양한 식품소재화가 이루어질 것으로 기대하는 바이다.

\section{감사의 글}

본 연구는 농촌진흥청 공동연구사업(과제번호: PJ011629) 의 지원에 의한 이루어진 것입니다. 


\section{References}

1. Jin TY, Wang MH, Yin Y, Eun JB (2008) Effect of Citrus junos peel on the quality and antioxidant activity of traditional rice wine, Jinyangju. J Korean Soc Food Sci Nutr, 37, 76-82

2. Lee SJ, Shin JH, Kang MJ, Jeong CH, Ju JC, Sung NJ (2010) Physicochemical properties, free sugar and volatile compounds of Korean citrons cultivated in different areas. J Korean Soc Food Sci Nutr, 39, 92-98

3. Shin JH, Lee JY, Ju JC, Lee SJ, Cho HS, Sung NJ (2005) Chemical properties and nitrite scavenging ability of citron (Citrus junos). J Korean Soc Food Sci Nutr, 34, 496-502

4. Kang SK, Jang MJ, Kim YD (2006) A study on the flavor constituents of the citron(Citrus junos). Korean J Food Preserv, 13, 204-210

5. Cha YJ, Lee SM, Ahn BJ, Song NS, Jeon SJ (1990) Substitution effect of sorbitol for sugar on the quality and storage stability of Yujacheong. J Korean Soc Food Sci Nutr, 19, 13-20

6. Kim DS, Kim DH, Oh MJ, Lee KG, Kook MC, Park CS (2010) Antiaging and whitening activities of ethanol extract of yuza (Citrus junos SIEB eib ex TANAKA) by-product. J Soc Cosmet Sci entists Korea, 36, 137-143

7. Nam HW, Hyun YH (2003) Drying of citron juice from by-product of citron tea manufacturing. Korean J Food Nutr, 16, 334-339

8. Jung JH (1974) Studies on the chemical compositions of Citrus junos in Korea. J Korean Agric Chem Soc, $17,63-80$

9. Lee HY, Seog HM, Nam YJ, Chung DH (1987) Phsicochemical properties of Korean mandarin orange juices. Korean J Food Sci Technol, 19, 338-345

10. Lee YC, Kim IH, Jeong JW, Kim HK, Park MH (1994) Chemical characteristics of citron (Citrus junos) juices. Korean J Food Sci Technol, 26, 552-556

11. Jeong JW, Kwon DJ, Hwang JB, Jo YJ (1994) Influence of the extraction method on quality of citron juice. Korean J Food Sci Technol, 26, 704-708

12. Jeong JW, Park KJ, Jung SW, Kim JH (1995) Changes in quality of citron juice by storage and extraction conditions. Agric Chem Biothechnol, 38, 141-146

13. Yoo KM, Hwang IK (2004) In vitro

effect of yuza(Citrus junos SIEB ex TANAK) extracts on proliferation of human prostate cancer cells and antioxidant activity. Korean J Food Sci Technol, 36,
339-344

14. Lee YJ, Hwang IG, Joung EM, Kim HY, Park ES, Woo KS, Jeong HS (2009) Physiological activity and antiproliferation effects of citron seed extracts on cancer cells. J Korean Soc Food Sci Nutr, 38, 1672-1678

15. Shin JH, Lee SJ, Kang MJ, Yang SM, Sung NJ (2009) Biological activities of yuza grown in different areas. J Korean Soc Food Sci Nutr, 38, 1485-1491

16. Shin JH, Choi DJ, Kwon OC (2007) Physical and sensory characteristics of sponge cakes added steamed garlic and yuza powder. Korean J Food Nutr, 20, 392-398

17. Yoo KM, Lee CH, Hwang IK (2008) Preparation of chocolate added with yuza(Citrus junos SIEB ex TANAKA) and its antioxidant characteristics. Korean J Food Cookery Sci, 24, 222-227

18. Kang SK, Jang MJ, Kim YD (2006) Isolation and culture conditions of Acetobacter sp. for the production of citron(Citrus junos) vinger. Korean J Food Preserv, 13, 357-362

19. Lee JS, Hong JS (2005) The quality characteristics of Sulgidduk with the addition of citron preserved in sugar. Korean J Food Cookery Sci, 21, 851-858

20. Kim SH, Choi DJ, Shin JH, Lee JY, Sung NJ (2004) Nutritional characteristics of ice cream added with citron(Citrus junos SIEB ex TANAKA) juice. Korean J Food Nutr, 17, 212-219

21. AOAC (1995) Official

Methods of Analysis. $16^{\text {th }}$ ed, Association of Official Analytical Chemists, Washington DC, USA. p 69-74

22. Davis WB (1947) Determination of flavanones in citrus fruits. Anal Chem, 19, 476-478

23. Hwang SH, Kim MJ, Kim KS (2013) Biochemical properties, volatile compounds and total phenol contents of yuza variety. Korean J Food Nutr, 26, 685-692

24. Dewanto V, Wu X, Liu RH (2002) Processed sweet corn has higher antioxidant activity. J Agric Food Chem 50, 4959-4964

25. Jia Z, Tang M, Wu J (1999) The determination of flavonoid contents in mulberry and their scavenging effects on superoxide radicals. Food Chem, 64, 555-559

26. Blois MS (1958) Antioxidant determinations by the use of a stable free radical. Nature, 181, 1199-1204

27. Re R, Pellegrini N, Pannala A, Yang M, and Rice-Evans C (1999) Antioxidant activity applying an improved ABTS radical cation decolorization assay. Free Radical Biol. Med, 26, 1231-1237

28. Song EY, Choi YH, Kang KH, Koh JS (1998) Free sugar, 
organic acid, hesperidin, naringin and inorganic elements change of Cheju citrus fruits according to harvest date. Korean J Food Sci Technol, 30, 306-312

29. Ji EJ, Yoo KM, Park JB, Hwang IK (2008) Preparation of citron peel tea containing yuza(Citrus junos SIEB ex
TANAKA) and its antioxidant characteristics. Korean J Food Cookery Sci, 24, 460-465

30. Cha JY, Cho YS (2001) Biofunctional activity of citrus flavonoids. J Korean Soc Agric Chem Biotechnol, 44, 122-128 